\title{
Soybean yield and yield components affected by the mycorrhiza and bradyrhizobium at different rates of starter nitrogen fertilizer
}

\section{Rendimento de soja e componentes de rendimento afetados pelas micorriza e bradyrhizobium em diferentes taxas de fertilizante de nitrogênio inicial}

\author{
Mohammad Ali Aboutalebian ${ }^{1 *}$; Masoumeh Malmir²
}

\begin{abstract}
In order to study interaction between mycorrhiza and bradyrhizobium on yield of soybean under different amounts of starter nitrogen fertilizer, a field experiment was conducted at the agricultural research station, Bu-Ali Sina University in 2015 growing season. A factorial experiment based on randomized complete block design was arranged with three replications. Experiment factors covering three levels of starter nitrogen of 0,30 and $60 \mathrm{~kg} \mathrm{ha}^{-1}$, bradyrhizobiumin two level of inoculated and non-inoculated and mycorrhiza including application and non-application levels. Results indicated that plant height, number of leaves per plant, yield and yield components and biological yield and mycorrhizal symbiosis percent affected by interaction of studied factors significantly. Maximum number of pod per plant achieved from combination of $30 \mathrm{~kg}$ Nitrogen and bradyrhizobium. Also both bio-fertilizers were able to increase number of pod per plant. Maximum 1000 seed weight obtained from inoculation of plants with bradyrhizobium and mycorrhiza simultaneously with no nitrogen utilization. Application of $60 \mathrm{~kg}$ $\mathrm{ha}^{-1}$ nitrogen reduced mycorrhizal symbiosis about 20.22 percent in comparison with no use of starter fertilizer. Application bradyrhizobium and mycorrhiza under the application of $30 \mathrm{~kg} \mathrm{ha}^{-1}$ nitrogen, produced the highest grain yield $\left(511.67 \mathrm{~g} \mathrm{~m}^{-2}\right)$ and biological yield $\left(1223.16 \mathrm{~g} \mathrm{~m}^{-2}\right)$.
\end{abstract}

Key words: Symbiosis percent. Bio-fertilizer. 1000 seed weight.

\section{Resumo}

Com o objetivo de estudar a interação entre micorriza e bradyrhizobium na produção de soja com diferentes quantidades de adubo nitrogenado de partida, realizou-se um experimento de campo na estação de pesquisa agrícola da Universidade Bu-Ali Sina em 2015. Um experimento fatorial baseado em delineamento de blocos ao acaso foi organizado com três repetições. Fatores experimentais que abrangem três níveis de nitrogênio inicial de 0,30 e $60 \mathrm{~kg} \mathrm{ha}^{-1}$, bradyrhizobium em dois níveis de inoculados e não inoculados e micorriza, incluindo os níveis de aplicação e não aplicação. Os resultados indicaram que a altura da planta, número de folhas por planta, rendimento e componentes de rendimento e rendimento biológico e percentagem de simbiose micorrízicaafectada pela interacção dos factores estudados significativamente. Número máximo de pod por planta obtido a partir da combinação de $30 \mathrm{~kg}$ de nitrogênio e bradyrhizobium. Também ambos os bio-fertilizantes foram capazes de aumentar o número de pod por planta. Peso máximo 1000 semente obtido da inoculação de plantas com bradyrhizobium e mycorrhiza simultaneamente com nenhuma utilização de nitrogênio. A aplicação de $60 \mathrm{~kg} \mathrm{ha}^{-1}$ de

\footnotetext{
1 Assistant Professor, Department of Agronomy and Plant Breeding, Faculty of Agriculture, Bu Ali Sina University, Hamedan, Iran. E-mail: aboutalebian@yahoo.com

2 M. Sc. Student of Agronomy, Faculty of Agriculture, Bu Ali Sina University, Hamedan, Iran. E-mail: m.malmir1359@gmail.

Author for correspondence
}

Received: Oct. 21, 2016 Approved: Dec. 15, 2016 
nitrogênio causou diminuição da simbiose micorrízica cerca de 20, 22 porcento em comparação com a ausência de adubação inicial. Aplicação bradyrhizobium e micorrizas sob aplicação de $30 \mathrm{~kg} \mathrm{ha}^{-1} \mathrm{de}$ nitrogênio, produziu o maior rendimento de grãos $\left(511.67 \mathrm{~g} \mathrm{~m}^{-2}\right)$ eo rendimento biológico (1223.16 $\mathrm{g}$ $\left.\mathrm{m}^{-2}\right)$.

Palavras-chave: Simbiose percentual. Bio-fertilizante. 1000 peso de semente.

\section{Introduction}

One of the most important problems in order to improve growth and yield increase of oil plants, is proper nutrition during growing season. In recent decades, ecological problems such as ground water pollution and destruction of soil structure in farm fields due to indiscriminate use of chemical fertilizers especially nitrogenous fertilizers, it is necessary to use ecological methods to supply at least part of nutrient elements especially nitrogen. So that biofertilizer utilization in agriculture is considered as an effective solution to decrease the chemical inputs consumption nowadays (CHALK et al., 2006). Legume plants (Fabaceae) such as soybean are able to supply part of their nitrogen needs through establishing symbiotic relationship with rhizobium bacteria. Reports indicate that until these plants root not enough polluted with the bacteria, applying proper quantity of starter nitrogen fertilizer is necessary to stimulate earlygrowth of plant (STARLING et al., 1998). In other words, these plants are unable to supply the whole need of nitrogen through symbiosis system (SYVERUD et al., 1980). Thus complementary nitrogen consumption through chemical fertilizer application is necessary for achieving maximum yield potential in these plants. Studying the effect of different amounts of starter nitrogen fertilizer in legume type plants cultivation have top research priority in this type of plants. It is reported in a study that pea seed inoculation (Cicer arietinum) with rhizobium bacteria along with 50 percent nitrogen fertilizer application the plant needs, cause biological yield and seed increase (SAINI et al., 2004). Also in effect of different amount of nitrogen fertilizer in pea survey, reported that applying $15 \mathrm{~kg}$ $\mathrm{ha}^{-1}$ and $30 \mathrm{~kg} \mathrm{ha}^{-1}$ nitrogen in addition to improving plant growth characteristics, made positive effect on biological nitrogen stabilization but higher quantity of starter fertilizer made inhibitory effect on rhizobium bacteria ability (WALLEY et al., 2005).

Today mycorrhiza fungi regarding their important roles for preparing and supplying nutrients and soil fertility improvement are under special attraction. These fungi an addition to improve plant growth and photosynthesis through increasing of absorption and transfer of water and nutrients and photosynthesis (RUIZ-SANCHEZ et al., 2010), increasing the concentration of plant hormones (CARDOSO; KUYPER, 2006) and increasing plant resistance against unfavorable environment condition (HEIDARI; KARAMI, 2014), can be effective on plant symbiosis with other microorganisms such as rhizobium bacteria too (CHALK et al., 2006). In fact, establishinga triple symbiosis relationship between plant as host, rhizobium bacteria and mycorrhiza fungicause plant growth improvement (ORTAS, 2008) and through amplifying each other effects, will play more effective role in quantitative and qualitative performance of the plants. In a study Salih et al. (2015) stated that application of rhizobium and mycorrhiza simultaneously due to resonance effect on each other, increased number and weight of nitrogen stabilization nodes, nitrogen, phosphorus and other nutrients absorption in plant and subsequently led to increase soybean yield. In surveying effect of twofold inoculation of mycorrhiza andRhizobium phaseoliondifferent type of beans (Phaseolus vulgaris) yield, reported that the performance of this plant under dual application of mycorrhiza fungi and rhizobium bacteria had considerable superiority than use of them individually (SAFA-POOR et al., 2010). 
Accordingly, in this research, the reaction of soybean yield and its components were studied to application of bradyrhizobium and mycorrhiza bio-fertilizers at different levels of nitrogen starter fertilizer.

\section{Materials and Methods}

This study was conducted at the agricultural research station, Bu-Ali Sina University (35 '1' $\mathrm{N}, 4831^{\prime} \mathrm{E}, 1690 \mathrm{~m}$ alt) in 2015 growing season. According to 55-year old meteorological statistics, the region has a semi-arid and cold climate with an average annual rainfall of $333 \mathrm{~mm}$ and average temperature of $24^{\circ} \mathrm{C}$ in the warmest month. The experiment was factorial based on complete randomized block design with three replications. First factor was starter nitrogen fertilizer in three levels of 0,30 and $60 \mathrm{~kg} \mathrm{ha}^{-1}$ of urea which was used at planting time. Second and third factors included Bradyrhizobium japonicum and mycorrhiza (Glomus mossea) bio-fertilizers, respectively, that each had two levels with and without application.

Each experimental unit contained six lines a distance of $50 \mathrm{~cm}$ and a length of $5 \mathrm{~m}$. Planting was done on May 31 with 40 plants per $\mathrm{m}^{2}$ density. Space of $1 \mathrm{~m}$ between each block was considered.
Physical and chemical characteristics of the soil was determined by sampling at a depth of 0 to 30 $\mathrm{cm}$ (table 1). Based on soil test, $100 \mathrm{~kg} \mathrm{ha}^{-1}$ triple superphosphate fertilizer was applied. Sprinkler irrigation performed every ten days. Soybean seed (M9, an indeterminate and early maturing cultivar) and Bradyrhizobium japonicum liquid inoculation provided from Hamedan oil seeds research center. There were $8.5 \times 10^{11}$ live and active bacteria per $\mathrm{ml}$ of rhizobial inoculant. Seed inoculation liquid was applied at a rate of one liter per hectare. Mycorrhiza arbuscular bio-fertilizer of Glomus mossea with 150 spores per gram, prepared from Zist Fannavaran Turan Shahrud company with Mycopersica brand, which based upon manufacturer recommendation, was applied amount of $20 \mathrm{~g} \mathrm{~m}^{-2}$ in strips near the seed at planting time. In order to evaluate biologic yield and seed yield, harvesting of $3 \mathrm{~m}^{2}$ from each plot was performed. To measure yield components, averages of 10 plants per plot were used. To determine mycorrhizal symbiosis percent of roots, staining method of Philips and Hayman (1970) was used. After normality test of residuals (ShapiroWilk test), based upon statistical model plan, data analyzed with SAS version 9.1. Means comparison was performed through least significant difference (LSD) at $\mathrm{P}=0.05$.

Table 1. Physical and chemical characteristics of the soil.

\begin{tabular}{ccccccccc}
\hline $\begin{array}{c}\text { Clay } \\
(\%)\end{array}$ & $\begin{array}{c}\text { Silt } \\
(\%)\end{array}$ & $\begin{array}{c}\text { Sand } \\
(\%)\end{array}$ & $\begin{array}{c}\text { Soil } \\
\text { texture }\end{array}$ & $\mathrm{pH}$ & $\begin{array}{c}\text { Organic } \\
\text { carbon }(\%)\end{array}$ & $\begin{array}{c}\text { Total } \\
\text { nitrogen }(\%)\end{array}$ & $\begin{array}{c}\text { Available potassium } \\
\left(\mathrm{mg} \mathrm{kg}^{-1}\right)\end{array}$ & $\begin{array}{c}\text { Available phosphorous } \\
\left(\mathrm{mg} \mathrm{kg}^{-1}\right)\end{array}$ \\
\hline 35 & 45 & 20 & Clay loam & 7.6 & 0.72 & 0.01 & 220 & 8.2 \\
\hline
\end{tabular}

\section{Results and Discussion}

\section{Number of pods per plant}

Analysis of variance showed that number of pods per plantwas influenced by the main effects of three factors, interaction of starter nitrogen fertilizer with bradyrhizobium and also interaction of bradyrhizobium with mycorrhiza (Table 2). Maximum number of pods per plant (25.79) was achieved in application of $30 \mathrm{~kg} \mathrm{ha}^{-1}$ nitrogen plus bradyrhizobium inoculation however it had no significant difference with the same treatment in the 
application of $60 \mathrm{~kg} \mathrm{ha}^{-1}$ nitrogen (Figure 1). Rajput with bradyrhizobium increased soybean yield et al.(2001) reported that soybean seeds inoculation components such as number of pod per plant.

Table 2. Analysis of variance for studied traits of soybean affected by Nitrogen, Bradyrhizobium and Mycorrhiza.

\begin{tabular}{|c|c|c|c|c|c|c|c|c|c|c|}
\hline \multirow[t]{2}{*}{ SOV } & \multicolumn{3}{|c|}{$\mathrm{DF}$} & \multirow{2}{*}{$\begin{array}{c}\begin{array}{c}\text { Pods/ } \\
\text { plant }\end{array} \\
50.79^{* *}\end{array}$} & \multirow{2}{*}{$\begin{array}{c}\begin{array}{c}\text { Seeds/ } \\
\text { pod }\end{array} \\
1.5^{* *}\end{array}$} & \multirow{2}{*}{$\begin{array}{c}1000 \text { seed } \\
\text { weight }\end{array}$} & \multirow{2}{*}{$\begin{array}{c}\begin{array}{c}\text { Seed } \\
\text { yield }\end{array} \\
8958.1^{* *}\end{array}$} & \multirow{2}{*}{$\begin{array}{c}\begin{array}{c}\text { Biological } \\
\text { yield }\end{array} \\
52343.6^{* *}\end{array}$} & \multirow{2}{*}{$\begin{array}{c}\begin{array}{c}\text { Harvest } \\
\text { index }\end{array} \\
0.15^{\text {ns }}\end{array}$} & \multirow{2}{*}{$\begin{array}{c}\begin{array}{c}\text { Inocula- } \\
\text { tion } \\
\text { percent }\end{array} \\
83.6^{* *}\end{array}$} \\
\hline & Block & & 2 & & & & & & & \\
\hline & $\mathrm{N}$ & & 2 & $26.70^{* *}$ & $0.58^{* *}$ & $168.2^{\mathrm{ns}}$ & $35823.6^{* *}$ & $92524.3^{* *}$ & $51.22^{* *}$ & $277.4^{* *}$ \\
\hline & $\mathrm{B}$ & & 1 & $41.17^{* *}$ & $1.36^{* *}$ & $1253.7^{* *}$ & $37650.2^{* *}$ & $206075.1^{* *}$ & $58.12^{*}$ & $318.4^{* *}$ \\
\hline & M & & 1 & $24.92^{* *}$ & $0.37^{*}$ & $649.9^{* *}$ & $36290.2^{* *}$ & $86497.7^{* *}$ & $68.75^{* *}$ & $46635^{* *}$ \\
\hline & $\mathrm{N} \times \mathrm{B}$ & & 2 & $12.25^{* *}$ & $0.11^{\mathrm{ns}}$ & $15.5^{\mathrm{ns}}$ & $3001.5^{*}$ & $13355.8^{*}$ & $13.38^{\text {ns }}$ & $6.2^{\mathrm{ns}}$ \\
\hline & $\mathrm{N} \times \mathrm{M}$ & & 2 & $1.14^{\mathrm{ns}}$ & $0.08^{\mathrm{ns}}$ & $43.7^{\mathrm{ns}}$ & $10995.1^{* *}$ & $35456.2^{* *}$ & $8.03^{\mathrm{ns}}$ & $257.3^{* *}$ \\
\hline & $\mathrm{B} \times \mathrm{M}$ & & 1 & $10.56^{*}$ & $0.15^{\mathrm{ns}}$ & $15.8^{\mathrm{ns}}$ & $10468^{* *}$ & $5950.8^{\mathrm{ns}}$ & $4.30^{\mathrm{ns}}$ & $10^{\mathrm{ns}}$ \\
\hline & $\mathrm{N} \times \mathrm{B} \times \mathrm{M}$ & & 2 & $1.42^{\mathrm{ns}}$ & $0.01^{\mathrm{ns}}$ & $259.7^{*}$ & $2830.7^{*}$ & $18214.4^{*}$ & $1.05^{\mathrm{ns}}$ & $7.6^{\mathrm{ns}}$ \\
\hline & Error & & 22 & 2.45 & 0.06 & 73.3 & 681.5 & 3432 & 8.58 & 9.8 \\
\hline \multicolumn{4}{|c|}{ Coefficient of Variation (\%) } & 6.73 & 10.69 & 5.11 & 6.72 & 5.73 & 7.74 & 7.09 \\
\hline
\end{tabular}

N: Starter nitrogen fertilizer, B: Bradyrhizobium and M: Mycorrhiza

**, *, ns: Significant at $1 \%$ and $5 \%$ probability level, Non-significant difference, respectively.

Figure 1. Number of pods per plant of soybean affected by interaction between Nitrogen and Rhizobium.

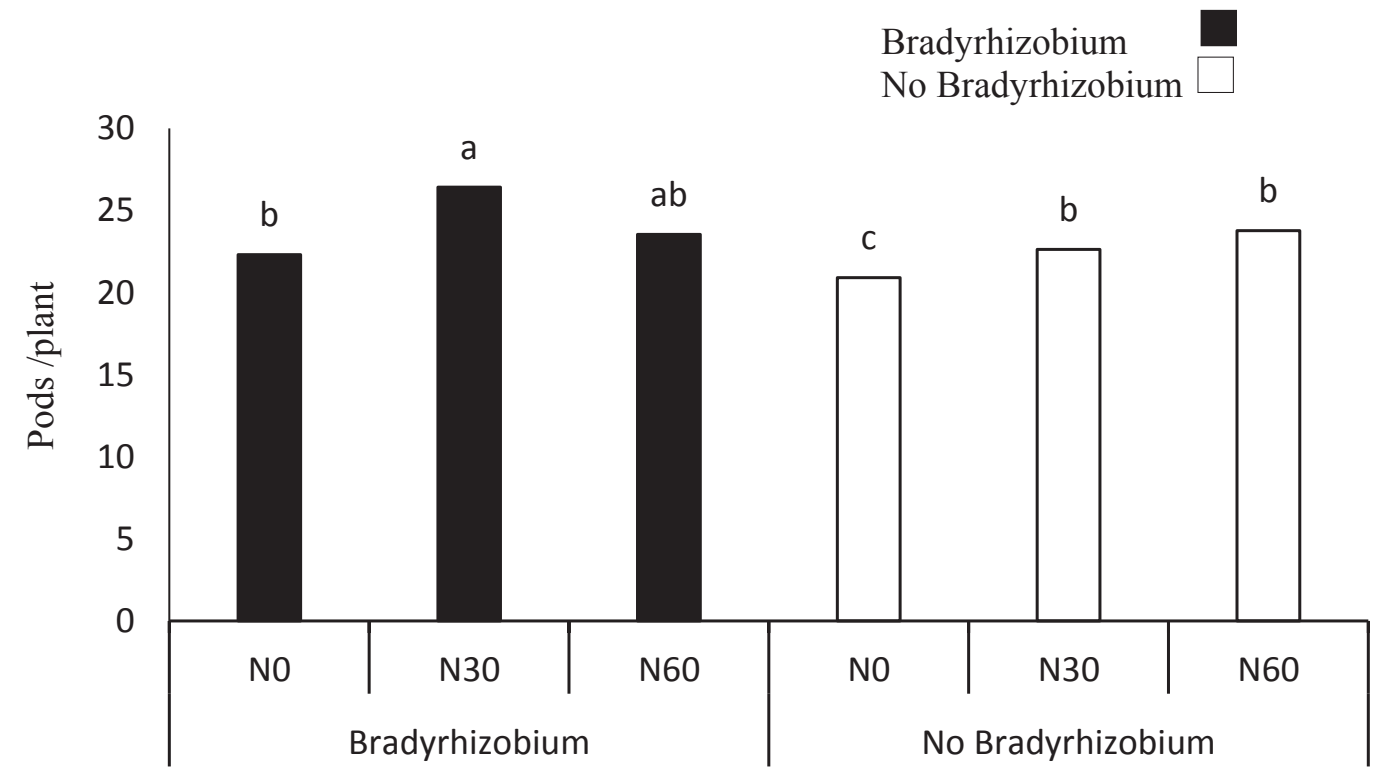


Figure 2 indicates that mycorrhiza and bradyrhizobium could increase number of pod per plant individually as well as together. Application of the both bio-fertilizers simultaneously led to 18.25 percent increase of pods number per plant compared with the non-application of them.

Mycorrhiza fungi can increase the ability of roots for absorbing macro and micro-nutrients and increasing phytohormones production through improving growth condition and plant photosynthesis (RUIZ-SANCHEZ et al., 2010). Also mycorrhiza fungi have positive and increasing effect on biological activity of rhizobiums which have symbiosis with the legumes root (ERMAN et al., 2011; SIVIERO et al., 2008; HEIDARI; KARAMI, 2014; RYAN; GRAHAM, 2002).

Figure 2. Number of pods per plant of soybean affected by interaction between Rhizobium and Mycorrhiza.

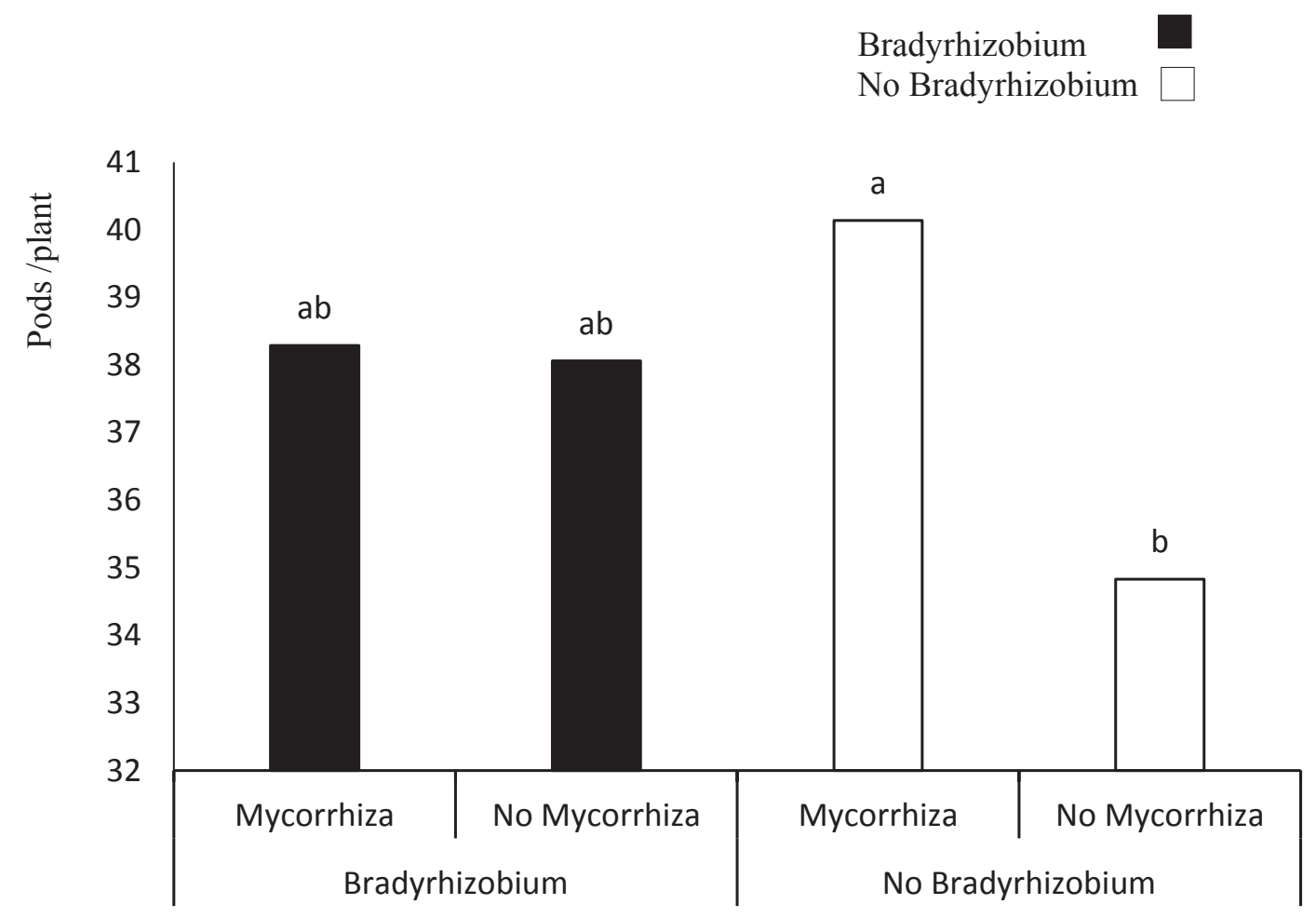

Number of seeds per pod

Main effects of nitrogen starterrate, rhizobium and mycorrhiza on number of seeds per pod were significant but interaction of used factors was not significant (Table 2). Maximum number of seeds per pod was achieved by applying $30 \mathrm{~kg} \mathrm{ha}^{-1}$ nitrogen starter (2.58). Probably more nitrogen consumption and its higher availability caused more vegetative growth of plant than reproductive growth and led to decrease in number of seeds per pod (ELSHAARAWI et al., 2011).
Inoculation with bradyrhizobium and mycorrhiza in comparison with non-inoculated plants, increased seed number per pod 18.05 and 9.33 percent, respectively (Table 3 ). Bradyrhizobium by fixing nitrogen and mycorrhiza by increasing the contact surface of roots with soil, cause increase nitrogen contentof plant (HEIDARI; KARAMI, 2014) and other nutrients absorption specially phosphorus (SALIH et al.,2015). Safa-poor et al. (2010) also reported that rhizobium and mycorrhiza increased significantly the number of seeds per pod and 
per beans plant. This is despite the report of Khalequzzaman and Hossain (2008) that expressed different levels of rhizobium and bio-fertilizers had not significant effect on number of seeds per pod.

\section{0 seed weight}

Based upon variance analysis results, the main effects of bradyrhizobium and mycorrhiza and triple interaction of surveyed factors were significant on 1000 seed weight (Table 2). The highest 1000 seed weight was obtained from the use of bio-fertilizers simultaneously with no nitrogen starter (180.63 g) (Table 4). Simultaneous application of bradyrhizobium and mycorrhiza had more effect compared with separately application of them. However, in $30 \mathrm{~kg} \mathrm{ha}^{-1}$ nitrogen level, also bradyrhizobium or mycorrhiza application individually produced a high 1000 seed weight. Increasing nitrogen consumption from $30 \mathrm{~kg} \mathrm{ha}^{-1}$ to $60 \mathrm{~kg} \mathrm{ha}^{-1}$ caused decreasing of seed dry weight (Table 4). In the present study nitrogen starter fertilizer application up to $30 \mathrm{~kg} \mathrm{ha}^{-1}$ had positive effect on seed dry weight but more nitrogen application caused decrease of 1000 seed weight confirming inhibitory effect of environment nitrogen on plant symbiosis with rhizobium that is correspond to Walley et al. (2005). It is reported in different types of soybean that rhizobium inoculation made more seed weight and seed yield in comparison with chemical fertilizer application (SOGUT, 2006). Therefore, to maximize production potential of soybean, application of starter nitrogen through chemical fertilizer is necessary (SYVERUD et al., 1980).

Table 3. Means comparison studied factors of soybean affected by Nitrogen, Bradyrhizobium and Mycorrhiza.

\begin{tabular}{ccccc}
\hline Studied factors & Leaves/ plant & Seeds/ pod & Harvest index (\%) & Inoculation (\%) \\
\hline Nitrogen & & & & \\
0 & $38.95^{\mathrm{b}}$ & $2.13^{\mathrm{c}}$ & $35.46^{\mathrm{b}}$ & $48.82^{\mathrm{a}}$ \\
30 & $47.50^{\mathrm{a}}$ & $2.58^{\mathrm{a}}$ & $39.22^{\mathrm{a}}$ & $44.35^{\mathrm{b}}$ \\
60 & $48.70^{\mathrm{a}}$ & $2.35^{\mathrm{b}}$ & $38.83^{\mathrm{a}}$ & $39.21^{\mathrm{c}}$ \\
\hline LSD $_{5 \%}$ & 7.49 & 0.21 & 2.48 & 3.48 \\
\hline Brady Rhizobium & & & \\
Inoculated & $49.05^{\mathrm{a}}$ & $2.55^{\mathrm{a}}$ & $38.8^{\mathrm{a}}$ & $47.10^{\mathrm{a}}$ \\
Control & $41.05^{\mathrm{b}}$ & $2.16^{\mathrm{b}}$ & $35.48^{\mathrm{b}}$ & $41.15^{\mathrm{b}}$ \\
\hline LSD ${ }_{5 \%}$ & 6.11 & 0.17 & 2.02 & 2.84 \\
\hline Mycorrhiza & & & & \\
Applicated & $51.27^{\mathrm{a}}$ & $2.46^{\mathrm{a}}$ & $39.21^{\mathrm{a}}$ & $80.12^{\mathrm{a}}$ \\
Control & $38.83^{\mathrm{b}}$ & $2.25^{\mathrm{b}}$ & $36.45^{\mathrm{b}}$ & $8.14^{\mathrm{b}}$ \\
\hline LSD $_{5 \%}$ & 6.11 & 0.17 & 2.02 & 2.84 \\
\hline
\end{tabular}

Means in each column, followed by similar letter are not significantly different by LSD at 5\% probability level. 
Table 4. Means comparison of studied traits of soybean affected by interaction between nitrogen, bradyrhizobium and mycorrhiza.

\begin{tabular}{|c|c|c|c|c|c|c|}
\hline \multicolumn{3}{|c|}{ Studied factors } & \multirow{2}{*}{$\begin{array}{l}\begin{array}{l}\text { Height } \\
(\mathrm{cm})\end{array} \\
67.67^{\mathrm{cd}}\end{array}$} & \multirow{2}{*}{$\begin{array}{c}1000 \text { seed weight } \\
(\mathrm{g})\end{array}$} & \multirow{2}{*}{$\begin{array}{c}\begin{array}{c}\text { Seed yield } \\
\left(\mathrm{g} \mathrm{m}^{-2}\right)\end{array} \\
367.23^{\mathrm{de}}\end{array}$} & \multirow{2}{*}{$\begin{array}{c}\begin{array}{c}\text { Biological yield } \\
\left(\mathrm{g} \mathrm{m}^{-2}\right)\end{array} \\
1049.6^{\mathrm{c}}\end{array}$} \\
\hline \multirow{4}{*}{ N1 } & $\mathrm{B}_{1}$ & $\mathrm{M}_{1}$ & & & & \\
\hline & & $\mathrm{M}_{2}$ & $58.33^{\mathrm{fg}}$ & $160.97^{\text {cdef }}$ & $321.12^{\mathrm{fg}}$ & $915.52^{\mathrm{d}}$ \\
\hline & $\mathrm{B}_{2}$ & $\mathrm{M}_{1}$ & $62.16^{\text {ef }}$ & 159.08 ef & $341.49^{\text {def }}$ & $901.81^{\mathrm{d}}$ \\
\hline & & $\mathrm{M}_{2}$ & $53.83^{\mathrm{g}}$ & $154.14^{\mathrm{f}}$ & $290.32^{\mathrm{g}}$ & $862.2^{\mathrm{d}}$ \\
\hline \multirow{4}{*}{$\mathrm{N} 2$} & $\mathrm{~B}_{1}$ & $\mathrm{M}_{1}$ & $78.33^{a b}$ & $175.66^{\mathrm{ab}}$ & $511.67^{a}$ & $1223.16^{\mathrm{a}}$ \\
\hline & \multirow{3}{*}{$\mathrm{B}_{2}$} & $\mathrm{M}_{2}$ & $73.16^{\mathrm{b}}$ & $178.28^{a b}$ & $445.48^{c}$ & $1119.04^{\mathrm{bc}}$ \\
\hline & & $\mathrm{M}_{1}$ & $73.5^{\mathrm{b}}$ & $175.24 \mathrm{abc}$ & $495.15^{\mathrm{ab}}$ & $1204.45^{\mathrm{ab}}$ \\
\hline & & $\mathrm{M}_{2}$ & $57.66 \mathrm{f}^{\mathrm{y}}$ & $155.57^{\mathrm{f}}$ & $301.17 \mathrm{f}^{\mathrm{g}}$ & $884.73^{\mathrm{d}}$ \\
\hline & $\mathrm{B}_{1}$ & $\mathrm{M}_{1}$ & $77.33^{\mathrm{ab}}$ & 174.67 abcd & $427.25^{c}$ & $1126.73^{\mathrm{abc}}$ \\
\hline & & $\mathrm{M}_{2}$ & $80.83^{a}$ & $170.2^{\mathrm{abcd}}$ & $451.37 \mathrm{bc}$ & 1147.95 abc \\
\hline & $\mathrm{B}_{2}$ & $\mathrm{M}_{1}$ & $73^{\mathrm{bc}}$ & $165.21^{\text {bcdef }}$ & $377.78^{d}$ & $916.41^{c}$ \\
\hline \multirow[t]{2}{*}{ N3 } & & $\mathrm{M}_{2}$ & $64.16^{\mathrm{de}}$ & $160.35^{\text {cdef }}$ & $330.12^{\mathrm{efg}}$ & $904.48^{c}$ \\
\hline & \multicolumn{2}{|c|}{$\operatorname{LSD}_{5 \%}$} & 5.42 & 14.50 & 44.20 & 99.21 \\
\hline
\end{tabular}

N1:0, N2:30 and N3:60 $\mathrm{kg} \mathrm{ha}^{-1}$ starter nitrogen fertilizer, B1: Bradyrhizobium, B2: No Bradyrhizobium, M1: Mycorrhiza and M2: No Mycorrhiza

Means in each column, followed by similar letter(s) are not significantly different at 5\% probability level (LSD).

\section{Seed yield}

Seed yield was influenced by all main effects and their interactions (Table 2). Regarding table 4 it can be seen simultaneous application of rhizobium and mycorrhiza plus $30 \mathrm{~kg} \mathrm{ha}^{-1}$ nitrogen starter fertilizer produced maximum seed yield $\left(511.67 \mathrm{~g} \mathrm{~m}^{-2}\right)$ which was 19.75 and 39.33 percent higher than same treatment plus $60 \mathrm{~kg} \mathrm{ha}^{-1}$ and no-nitrogen treatment, respectively. Present study results correspond to Erman et al. (2011) and Garg and Chandel (2011) on positive effect of simultaneous application of rhizobium and mycorrhiza in pea. However it has been reported that inoculation soybean seeds with bradyrhizobium by increasing nodulation and nitrogen fixation, caused 57 percent increase in soybean yield (ZIMMER et al., 2016). Based on the results, at $30 \mathrm{~kg} \mathrm{ha}^{-1}$ nitrogen level, mycorrhiza application alone, increased yield statistically equal to simultaneous application of mycorrhiza and bradyrhizobium treatment (Table 4) that indicates the key role of mycorrhiza in improving nutrients absorption specially nitrogen and phosphorus (RYAN; GRAHAM, 2002; CARDOSO; KUYPER, 2006). Starling et al. (1998) reported nitrogen application as starter fertilizer is necessary until the beginning of root symbiosis with rhizobia. Of course, excessive application of nitrogen causes decrease in plant performance by lowering biological activity of the root-rhizobia system (EL-SHAARAWI et al., 2011). However, in no-fertilizer application, inoculation and non-inoculation of soybean with bradyrhizobium are in a same statistical group that would be indicate necessity of starter nitrogen fertilizer application. Shiri Janagard et al. (2013) reported that rhizobium application plus 33 percent chemical fertilizer increased significantly soybean yield but at 100 percent chemical fertilizing plus rhizobium treatment, the yield was decreased. 


\section{Biological yield}

All factors and their interactions except for bradyrhizobium and mycorrhiza were significantly effective on biological yield (Table 2). Maximum biologicalyield was achieved by $30 \mathrm{~kg} \mathrm{ha}^{-1}$ nitrogen plus rhizobium inoculation and mycorrhiza application treatment that in comparison with control treatment (no biofertilizer and no nitrogen) caused 41.86 percent increase in biological yield of the plant (Table 4).

The results are similar to seed yield results. The difference is that biological yield unlike seed yield did not reduced significantly at $60 \mathrm{~kg} \mathrm{ha}^{-1}$ nitrogen starter fertilizer while there was bradyrhizobium (Table 4).

Adequate nitrogen existence as starter with presence of rhizobium causes increase of plant growth and yield but in high levels of nitrogen the plant performance decrease due to adverse effect on rhizobium bacteria activity and decrease of nitrogen fixing enzymes production (STARLING et al., 1998).

\section{Harvest index}

Different starter nitrogen fertilizer levels, bradyrhizobium inoculation and mycorrhiza application had significant effect on soybean harvest index (Table 2). Applying $30 \mathrm{~kg} \mathrm{ha}^{-1}$ nitrogen had maximum harvest index hadn't significant difference with $60 \mathrm{~kg} \mathrm{ha}^{-1}$ nitrogen treatment (Table 3). Also soybean seed inoculation with bradyrhizobium and mycorrhiza application increased soybean harvest index 9 and 7 percent, respectively (Table 3). This might happen due to direct and/or indirect effects of hormones of these microorganisms on the plant (DAKORA, 2003). Safa-poor et al. (2010) reported application of mycorrhiza and rhizobium increased bean yield by increasing harvest index.

\section{Mycorrhizal symbiosis percent}

Results of this study showed that surveyed factors had significant effect on plant symbiosis with mycorrhiza. Also plant inoculation with mycorrhiza was influenced by interaction between mycorrhiza and nitrogen levels (Table 2). So that increasing of nitrogen application had negative effect on root plant inoculation with mycorrhiza. Maximum inoculation percent was observed in mycorrhiza application and zero fertilizer level (Figure 3). There is a little information about mechanisms of nitrogen on mycorrhizal symbiosis. However, researches indicated that plant supply with more nitrogen as ammonium and nitrate combination, prevent plant symbiosis with mycorrhiza (CARDOSO; KUYPER, 2006). 
Figure 3. Percent of mycorrhiza inoculation affected by interaction between Nitrogen and Mycorrhiza.

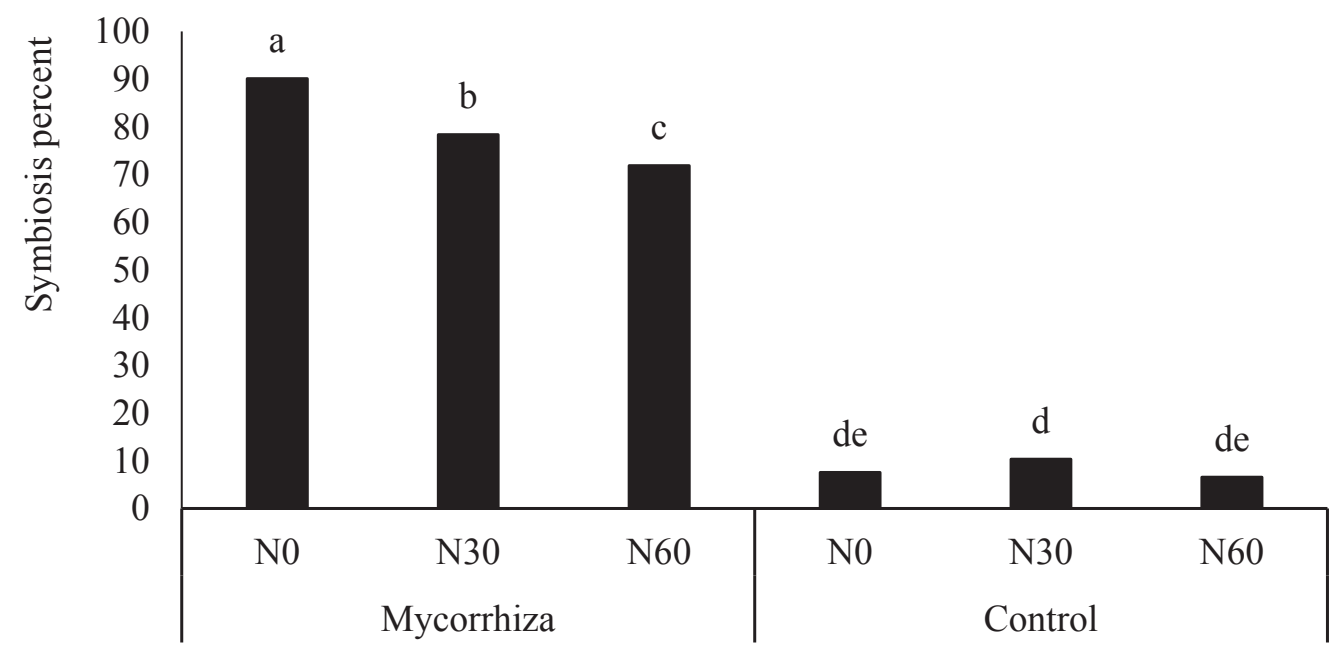

\section{Conclusions}

Results of present study indicated that seed yield, biological performance and 1000 seed weight of soybean were significantly affected by starter nitrogen, bradyrhizobium and mycorrhiza. In all nitrogen starter levels, mycorrhiza and bradyrhizobium application increased soybean yield. Using nitrogen starter up to $30 \mathrm{~kg} \mathrm{ha}^{-1}$, had positive effect on soybean yield components, but more nitrogen starter $\left(60 \mathrm{~kg} \mathrm{ha}^{-1}\right)$ in the presence of both fertilizers, had no effect on biological yield and 1000 seed weight also reduced grain yield in comparison with application of $30 \mathrm{~kg} \mathrm{~N} \mathrm{ha}^{-1}$. In this study, the use of bio-fertilizers increased soybean harvest index. Generally, application of $30 \mathrm{~kg} \mathrm{ha}^{-1}$ starter nitrogen along with simultaneous use of bradyrhizobium and mycorrhiza application, is recommended as superior treatment which can lead to the reduction of the consumption of nitrogen starter fertilizer in soybean.

\section{References}

CARDOSO, M.; KUYPER, T.W. Mycorrhizal and tropical soil fertility. Agriculture,Ecosystem and Environment, Amsterdam, v. 116, n. 1-2, p. 72-84, 2006.
CHALK, P. M.; SOUZA, R. D. F.; URQUIAGA, S.; ALVES, B. J. R.; BODDEY, R. M. The roleof Arbuscular mycorrhiza in legume symbiotic performance. Soil Biology and Biochemistry, Amsterdam, v. 38, n. 9, p. 2944-2951, 2006.

DAKORA, F. D. Defining new roles for plant and rhizobial molecules in sole and mixed plant cultures involving symbiotic legumes. New Phytologist, Cambridge, v. 157, n. 1, p. 39-49, 2003.

El-SHAARAWI, A. I.; SABH, A. Z.; ABOU-TALEB, S. M.; GHONIEM, A. E. Effect of inorganic nitrogen and Bradyrhizobium japonicum inoculation on growth and yield of soybean. Australian Journal of Basic and Applied Sciences, v. 5, n. 10, p. 436-447, 2011.

ERMAN, M.; DEMIR, S.; OCAK, E.; TUFENKCI, S.; OGUZ, F.; AKKOPRU, A. Effects of rhizobium, arbuscular mycorrhiza and whey applications on some properties in chickpea (Cicer arietinum L.) under irrigated and rainfed conditions 1-Yield, yield components, nodulation and AMF colonization. Field Crops Research, Amsterdam, v. 122, n. 1, p. 14-24, 2011.

GARG, N.; CHANDEL, S. Effect of mycorrhizal inoculation on growth, nitrogen fixation and nutrient uptake in Cicer arietinum under salt stress. Turkish Journal of Agriculture and Forestry, Ankara, v. 35, n. 1,205-214, 2011.

HEIDARI, M.; KARAMI, V. Effects of different mycorrhiza species on grain yield, nutrient uptake and oil content of sunflower under water stress. Journal of the Saudi Society of Agricultural Sciences, Amsterdam, 
v. 13, n. 1, p. 9-13, 2014.

KHALEQUZZAMAN, K. M.; HOSSAIN, I. Effect of seed treatment with rhizobium strains and biofertilizers on foot, root rot and yield of bushbean in Sclerotinia sclerotiorum infested soil. Journal of Bio-Science, Rajshahi, v. 16, n. 1, p. 73-78, 2008.

ORTAS, I. The effect of mycorrhizal inoculation on forage and non-forage plant growth and nutrient uptake under field conditions. Options Mediterranéennes, Montpellier, v. 79, n. 1, p. 463-469, 2008.

PHILIPS, J.; HAYMAN, D.S. Improved procedure for cleaning roots and staining parasitic and vesicular arbuscular mycorrhiza fungi for rapid assessment of infection. Transactions of the British Mycological Society, London, v. 55, n. 1, p. 158-161, 1970.

RAJPUT, L. S.; ANSARI, A. H.; USMANI-KHAIL, M. U.; OAD, F. C.; OAD, N. L. Vegetative growth, yield components and seed yield response of inoculated and un-inoculated soybean regard to fertility regimes. Journal of Applied Science, Dubai, v. 1, n. 3, p. 379-382, 2001.

RUIZ-SANCHEZ, M.; AROCA, R.; MUNOZ, Y.; POLON, R.; RUIZ-LOZANO, J. M. The arbuscular mycorrhizal symbiosis enhances the photosynthetic efficiency and the antioxidative response of rice plants subjected to drought stress. Journal of Plant Physiology, Jena, v. 167, n. 11, p. 862-869, 2010.

RYAN, M. H.; GRAHAM, J. H. Is there a role for arbuscular mycorrhizal fungi in production agriculture? Plant and Soil, Dordrecht, v. 244, n. 1, p. 263-271, 2002.

SAFA-POOR, M.; ARDAKANI, M. R.; REJALI, F.; KHAGHANI, S. H.; TEYMURI, M. Effect of coinoculation of mycorrhiza and rhizobium on common bean (Phaseolus vulgaris L.). New Finding in Agriculture, Arak, v. 5, n. 1, p. 21-35, 2010.

SAINI, V. K.; BHANDARI, S. C.; TARAFDAR, J. C. Comparison of crop yield, soil microbial $\mathrm{C}, \mathrm{N}$ and $\mathrm{P}$, $\mathrm{N}$ fixation, nodulation and mycorrhizal infection in inoculated and non-inoculated sorghum and chickpea crops. Field Crops Research, Amsterdam, v. 89, n. 1, p. 39-47,2004.
SALIH, S. H.; HAMD, S. A. M.; DAGASH, Y. M. I. The effects of rhizobium, mycorrhizal inoculation and diammonium phosphate (DAP) on nodulation, growth, and yield of soybean. Universal Journal of Agricultural Research, California, v. 3, n. 1, p. 11-14, 2015.

SHIRI JANAGARD, M.; RAEI, Y.; GASEMIGOLEZANI, K.; ALIASGARZAD, N. Soybean response to biological and chemical fertilizers. International Journal of Agriculture and Crop Science, London, v. 5, n. 3, p. 261-266, 2013.

SIVIERO, M. A.; MOTTA, A. M.; SANTOS LIMA, D. dos; BIROLLI, R. R.; HUH, S. Y.; SANTINONI, I. A.; NOGUEIRA, M. A. Interaction among N-fixing bacteria and AM fungi in Amazonian legume tree (Schizolobium amazonicum) in field conditions. Applied Soil Ecology, Amsterdam, v. 39, n. 2, p. 144-152, 2008.

SOGUT, T. Rhizobium inoculation improves yield and nitrogen accumulation in soybean (Glycine max L.) cultivars better than fertilizer. New Zealand Journal of Crop and Horticultural Science, Abingdon, v. 34, n. 2, p. 115-120, 2006.

STARLING, M. E.; WOOD, C. W.; WEAVER, D. B. Starter nitrogen and growth habit effects on late-planted soybean. Agronomy Journal, Madison, v. 90, n. 5, p. 658$662,1998$.

SYVERUD, T. D; WALSH, L. M.; OPLINGER, E. S.; KELLING, K. A. Foliar fertilization of soybeans (Glycine max L.). Communications in Soil Science and Plant Analysis, Philadelphia, v. 11, n. 6, p. 637-651, 1980.

WALLEY, F. L.; BOAHEN, S. K.; HNATOWICH, G.; STEVENSON, C. Nitrogen and phosphorus fertility management for desi and kabuli chickpea. Canadian Journal of Plant Science, Ottawa, v. 85, n. 1, p. 73-79, 2005.

ZIMMER, S.; MESSMER, M.; HAASEC, T. H.; PIEPHO, H. P.; MINDERMANN, A.; SCHULZ, H.; HABEKUB, A.; ORDON, F.; WILBOIS, K. P.; HEB, J. Effects of soybean variety and Bradyrhizobium strains on yield, protein content and biological nitrogen fixation under cool growing conditions in Germany. European Journal of Agronomy, Amsterdam, v. 72, n. 1, p. 38-46, 2016. 